\title{
Power, Politics, and Musical Commemoration: Western Musical Figures in the People's Republic of China 1949-1964
}

\section{HON-LUN YANG}

The commemoration of prominent musical figures is a well recognized feature of Western musical culture. In 2006, many nations and cities joined in the commemoration of Mozart's 250th birthday. In 2002, ceremonies in Austria, France, Germany, Switzerland, and the United States marked the $200^{\text {th }}$ birthday of Hector Berlioz. Some twenty years earlier, in 1985, numerous events were held to commemorate the $400^{\text {th }}$ and $300^{\text {th }}$ birthdays of Heinrich Schutz, Johann Sebastian Bach, and George Frederick Handel respectively. It is more than common to have musical events and Festschriften pay tribute to composers, musical institutions, performers, and scholars.

In the People's Republic of China, there were also frequent national commemorations of Western musical figures, ${ }^{1}$ especially during the early years of the country's history: in 1954, Glinka's $150^{\text {th }}$ birthday and the $50^{\text {th }}$ anniversary of Dvořák's death; in 1956, Mozart's $200^{\text {th }}$ birthday and the centenary of Robert Schumann's death; in 1957, the centenary of Glinka's death and the $130^{\text {th }}$ anniversary of Beethoven's death; in 1958, Paul Robeson's $60^{\text {th }}$ birthday, the centenary of Puccini's birth, and the $50^{\text {th }}$ anniversary of Rimsky-Korsakov's death as well as the $20^{\text {th }}$ anniversary of Feodor Chaliapin's death; in 1959, the bi-centenary of Handel's death; in 1960, 120 $0^{\text {th }}$ anniversary of Tchaikovsky's birth and the sesquicentennial of Chopin's birth; in 1961, the sesquicentennial of Liszt's birth.

Why did the People's Republic of China (hereafter as the PRC) join in the celebration of Western musical figures when China has a musical culture of her own? What were the meanings of these commemorations? It has been recognized that there are as many forms of commemorations as their roles and functions in a society, and the study of commemorations is a means of understanding the cultural contexts, the ideology and politics of a country. As pointed out in various studies, commemoration is a way of establishing national identity, ${ }^{2}$ whereas places of commemoration,

1 The term 'West' is originally a geographical concept, but as it is used today, its designation is often beyond the boundary of geography. Before the 19th century, the term 'West' is used synonymously with 'Europe' in China as well as in contemporary writings on China prior to the 19th century. But the term 'West' in its current use (prior to the break down of the Soviet / East Europe bloc countries) refers to countries of Western Europe and North America, the countries of the North Atlantic Treaty Organization which was formed in 1949, then thought as necessary to counter the military power of the Soviet Union. As a result, the term 'West' in common usage refers to not only those countries of NATO, but also the ideologies and value systems those countries uphold. But in this article, the term 'Western music' or 'Western musical figures' is used independent of political or ideological distinction between the NATO countries and the Soviet/East Europe bloc countries. The term 'Western' merely signifies the musical tradition of the West, and likewise the countries whose musical heritage are within this tradition.

2 For instance, see Lyn Spillman's Nation and Commemoration: Creating National Identities in the United States and Australia (New York: Cambridge University Press, 1997); it is also explored in Joachim Wolschke-Bulmahn ed., Places of Commemoration: Search for Identity and Landscape Design (Washington, D.C.: Dumbarton Oaks Research Library and Collection, 2001). 
monuments and landscape designs are the embodiments of identity. ${ }^{3}$ While commemoration is a way of forgetting, of healing the hurt, ${ }^{4}$ it is also a way of using the past to serve the present, with each past and present individual event tied into a particular sociopolitical context. ${ }^{5}$ For instance, historian William Weber notes that the British commemoration of Handel in 1784 was not only a musical event, but a political one: it captured public attention and made Handel's music a national agenda “on the heels of constitutional crisis-dispute over the authority of crown and parliament, the Fox-North ministry of 1783, and the turbulent election of 1784." 6

Ethnomusicologist Philip V. Bohlman proclaimed, "We study music to understand more about cultural contexts, about ideology and politics, about the ways in which language functions, about gender and sexuality, and about the identities of cultures ranging from the smallest group to the most powerful nation." ${ }^{\prime 7}$ In this article, through the study of musical commemorations in the PRC (from 1949 to 1964), I hope to address the following issues. What did Western music embody for Chinese people of the People's Republic of China in this period? Why did the communist leaders feel the need to embrace Western music and musical figures? What did the commemorative events tell us about the communist leadership's vision of China's development and its place in the international community? Most importantly, why and how were musical commemorations treated as one of the strategies to attain their goals?

\section{A background of the PRC (1949-1964) and Western music in China}

The period between 1949 and 1964 in the PRC witnessed more than a handful of state-level commemorations of Western musical figures. It was a period, according to Lawrence Sullivan, "marked by political turbulence and transformation but with substantial progress in economic growth, public health, and social-economic infrastructure." The Chinese Communist Party's (hereafter as CCP) defeat of the Nationalist Party in 1949 led to the founding of the PRC on October 1. There was much to be done by the new government both internationally and domestically in the face of the emerging Cold War as well as the need to rebuild a country damaged by inflation and civil war, and moving toward socialism and communism. Internationally, China sided with the Soviet Union, and her entering the Korean War put her in further opposition to the US. Domestically, various political, economic, and social measures were introduced to pave the way for socialism, land reform, state organization and collective ownership of enterprises, and the setting up of the communes, to name but a few. To ensure the smooth running of a totalitarian government, state control was asserted over the media and all institutions of learning. Political differences were mute and political opponents such as Western educated intellectuals were subject to severe persecution in a series of political campaigns,

3 See Sarah Bonnemaison, "Places and Memory: Multiple Readings of a Plaza in Paris during the Commemoration of the French Revolution," in Dana Arnold and Andrew Ballantyne eds., Architecture as Experience: Radical Change in Spatial Practice (New York: Routledge, 2004).

4 See Adrian Forty and Susanne Küchler eds., The Art of Forgetting (New York: Berg, 1999).

5 See Barry Schwartz, “The Social Context of Commemoration: A Study in Collective Memory," Social Forces 61/2 (1982): 374-402.

6 “The 1784 Handel Commemoration as Political Ritual," Fournal of British Studies 28 (1989): 43.

7 Philip V. Bohlman, “Music as Representation,” Fournal of Musicological Research 24 (2005): 205.

8 Historical Dictionary of the People's Republic of China: 1949-1997 (Lanham: Scarecrow Press, 1997), 4. 
such as the "Three Antis" and "Five Antis" in 1951 and 1952 respectively as well as the "Anti-Rightist Campaign" in 1957, shortly after a brief period of tolerance for intellectual freedom and free speech known as the "Hundred Flowers" in 1956. The economic policy introduced in 1958 by Mao Zedong to dramatically increase agricultural and steel production so as to catch up with major industrial powers--especially Britain--within 15 years (known as the "Great Leap Forward" and lasting from 1958 to 1960) resulted in catastrophe: drastic reductions in food supply from inefficient communes and the production of millions of tons of worthless steel from blasting household items in backyard furnaces. A period of recovery in economic and cultural sectors came in 1962 following Liu Shaoqi's ascension to power. But the worsening of Sino-Soviet conflict in 1963 and the tightening of political control in 1964 brought the country to the heel of the Cultural Revolution to be erupted in full force in 1966, and lasting until 1976.

Mirroring the turbulent history of the country, musical development in the PRC prior to 1966 went through similar ups and downs. It comes as no surprise that the CCP leaders were quick to mobilize the musical forces to serve the socialist call. Music conservatories were established in major cities, Western orchestras were founded, and the Chinese National Orchestra was built based on Western models. The Central Conservatory of Music was established in 1950 in Beijing, and the founding of music schools in secondary cities such as Shenyang, Chengdou, and Wuhan were to follow. ${ }^{9}$ Various amateur ensemble groups previously known as "Cultural Troupes" established by the CCP for propaganda purposes in the Republican era were reorganized to become professional performing groups such as symphony orchestras, Chinese national orchestras, and dance companies. In Bejing alone, there were the Central National Dance Troupe, the Chinese Broadcasting National Orchestra, and then the Beijing Symphony Orchestra of the Documentary Movie Studio. ${ }^{10}$

The CCP's embracing of Western-formatted musical ensembles has to be understood in the context of Western music in China. China is a country with a distinctive indigenous musical tradition that has incorporated various forms of foreign influences at different stages of its development. While Western music was brought to the Ming court by Jesuit missionaries as early as the early $17^{\text {th }}$ century, ${ }^{11}$ Western music's imposing existence on Chinese soil was only felt after China was forced to open her doors to Western missionaries and merchants as a result of China's total defeat by Britain in the Opium War in mid $19^{\text {th }}$ century. After a series of further defeats by Western powers, and only then, did China come to the realization that there had been a fundamental change in the power relations between the East and West. By the end of the $19^{\text {th }}$ century, Western bands and orchestras, and likewise Western musical instrumental players began to flourish in treaty ports such as Shanghai and Canton. Western melodies were introduced to the school curriculum -one of several political, social and economic reforms initiated by the Qing government in a hopeless attempt to save an empire that nevertheless collapsed in 1911. ${ }^{12}$ In conjunction with the 1919 New Culture Movement,

9 WANG Yuhe, Zhongguo jinxiandai yinyueshi [Music History of Contemporary China] (Beijing Gaodeng jiaoyu chubanshe, 2006), 2-3..

10 Ibid, 8.

11 For more information on musical exchange between China and the West prior to the 19th century, see Chapter 2 in Melvin and Cai's book Rhapsody in Red: How Western Classical Music Became Chinese (New York: Algora Publishing, 2004), and TAO Yabing's Zhongxi yinyue jiaoliu shigao [A History of Musical Exchanges between China and the West] (Beijing: Zhongguo dabaike quanshu chubanshe, 1994).

12 For a more detailed discussion on the development of Western music in China during the early 20th century, see B. 
the 1920 s and 1930 s witnessed a massive importation of Western music, the founding of Westernstyle conservatories to train Chinese musicians, the emergence of various Western orchestras and musical institutions all run by Chinese intellectuals, which were seen as creating a new China with a new musical art form - that is, Western music embedded with a Chinese spirit. As Chinese intellectuals then justified, Chinese music, often dubbed "unscientific," was backward and did not measure up to Western music in its notation, teaching method, and musical complexity. ${ }^{13}$ Indeed, it was this colonization of the Chinese consciousness, as historian James Hevia noted, that led to a whole new way of thinking on China's part about the world. ${ }^{14}$

During the Nationalist period, members of the CCP (founded in 1921) were also quick to see the potential power of "new music" to spread socialist ideology. Shanghai, the cradle of Chinese communism nourished the first generation of left-wing cultural workers (wenyi gongzuozhe), writers, playwrights, movie makers as well as composers and musicians. Nie Er (1912-1935), Ren Guang (1900-1941), Zhang Chu (1909-1938), Lü Ji (1909-2001) were the leading musical activists of the 1930s who engaged in producing mass songs of revolutionary and anti-Japanese contents. ${ }^{15}$ In 1938 , leaders of the CCP founded the Luxun Arts Academy in Yan'an, the communist base camp, the breeding ground of socialist Chinese art. "Folk opera" (yanggeju) and "new opera" (xingeju) as well as other musical genres such as mass songs and large-scale choral works were cultivated at the Academy. ${ }^{16}$

As seen by Mao Zedong, art and music were a crucial weapon in the revolutionary process -- the 'cultural army' was to help with the 'army with guns' to defeat the enemies, and the new socialist culture was going to reduce the impact of feudal culture of the old society and comprador culture of the imperialist. ${ }^{17}$ Western music was not rejected by Mao or the party leaders, but instead, seen as an art form that could be revamped to serve the new society and its people. "Revolutionary art and literature are the products of the brains of revolutionary artists and writers reflecting the life of the people. .. . We must take over all the fine artistic and literary legacy, critically assimilate from it what

Mittler, Dangerous Tunes. The Politics of Chinese Music in Hong Kong, Taiwan, and the People's Republic of China since 1949 (Wiesbaden: Harrassowitz, 1997); LIU Ching-chih's Zhongguo xinyinyue shilun [History of Chinese New Music] (Taibei: Yaowen chubanshe, 1998), and Melvin and Cai's Rhapsody in Red.

13 For Chinese intellectuals' writings on "new music," as the format of the music of the West was called in the 1930s and 1940s, see ZHANG Jingwei, ed. Zhongguo jinxiandai yinyue wenlun xuanbian [Selected Writings on Contemporary Chinese Music] (Shanghai: Shanghai yinyue chubanshe, 2004).

14 James Hevia, English Lessons (Durham: Duke University Press, 2003), 333.

15 For more information on the Left-wing Musical Movement, see WANG Yuhe, Zhongguo jinxiandai yinyueshi [Music History of Contemporary China] (Gaodeng jiaoyu chubanshe, 2006), 132-153; and XIA Yan, Zhongguo jinxiandai yinyueshi jianbian [A Brief History of Contemporary Chinese Music] (Shanghai yinyue chubanshe, 2004), 162-172.

16 Yanggeju originated from the yangge of north China, a variety of dances, songs and folk plays performed during the Chinese New Year until the Lantern Festival. This local art form, then seen as an apt ideological tool to create a new society, underwent dramatic transformations in the hands of the Yan'an composers. The newly composed yanggeju, such as Brother and Sister Clear Wasteland (Xiongmei kaihuang) and The Couple Learning to Read (Fuqi shizi), while retaining the format of the yangge, were propagandistic in their themes. For more information on the development of Yangge, see David Holm's detailed study Art and Ideology in Revolutionary China (Oxford: Oxford University Press, 1991). Xingeju originated from the opera of the Western world that began to fascinate Chinese intellectuals in the 1920s. Throughout the 20s and 30 s, there were attempts to signify the genre and in Yan'an, the efforts resulted in such socialist classics such as The Whitehaired Girl (Bai mao nu) and Liu Hulan, see Wang, 275-282.

17 Mao Tse-tung (Mao Zedong), Talks at the Yenan Forum on Art and Literature (Peking: Foreign Languages Press, 1956$), 1$. 
ever is beneficial to us and hold it up as an example when we try to work over the artistic and literary raw material derived from the people's life of our own time and place."18

\section{Commemoration as ritual}

While commemorating Western musical figures is a sincere gesture on China's part to show her appreciation of the cultural legacy of the Western world, the early commemorations were often treated as state events marked by ritualistic features that bore layers of meaning. The commemoration of the fiftieth anniversary of Dvořák's death in 1954 began with a concert held in Beijing on 24 May 1954. The concert program bore the names of several official organizations, including the Chinese People Defend World Peace Council (a subsidiary of the World Peace Council), ${ }^{19}$ the Foreign Affairs Cultural Bureau, the Association for Chinese Literature and Art, and The Association of Chinese Musicians. The concert was also attended by foreign dignitaries, including Consul General of Czechoslovakia. $^{20}$ The first part of the concert featured an opening address by Ding Xilin, the vicepresident of the Foreign Affairs Cultural Bureau. This was followed by introductions to Dvořák's life and works presented by Ma Sicong, the vice-president of the Society of Chinese Musicians, and by the Czech Consul General. The second part comprised performances of Dvořák's works by the Central Philharmonic: the program included Carnival Overture, Slavonic Dances, "New World" Symphony, and a selection of songs sung in Chinese and Czech. ${ }^{21}$ In conjunction with the commemoration, an exhibition was hosted for two weeks at the Beijing Library; the exhibition featured Dvořák's scores, some sixty photographs and other illustrations related to his life and works, and a variety of books and articles in Chinese, Czech, and German. A recent book on Dvořák translated from Czech to Chinese received special attention. ${ }^{22}$

The 1959 Handel celebration was similar in several respects. It too included an official commemorative concert, held on 14 April, which was organized by the same group of organizations and attended by important cultural figures as well as representatives of the German Democratic Republic and other countries. Introductory remarks were presented by Mao Dun, the vice-president of the Society of Chinese Literature and Art, as well as by the East German Consul General. Next was a concert of Handel's works performed by the Central Movie Studio Orchestra and the Central Philharmonic, including Handel's Concerto Grosso, Op. 6, No. 6, as well as a few instrumental sonatas, and excerpts from his operas and oratorios. ${ }^{23}$

18 Ibid., 22-23.

19 The World Peace Council (or World Council of Peace) was formed in 1949 to promote peaceful coexistence and nuclear disarmament. Its active participants were the Soviet / Eastern Europe bloc countries.

20 A description of the commemorative event can be found in a report by an author merely identified as "Jizhe" (reporter), "Zhongguo renmin jinian Dewoxiake" [Chinese people commemorated Dvořák"], Renmin Yinyue (June 1954$)$ : 17.

21 Ibid.

22 Ibid.

23 ZHAO Feng, "Jinian deguo weida de zuoqujia Qiao. Fo. Hengdeer shishi erbai zhounian” [In commemoration of the great German composer George Federic Handel's 200th death], Renmin Yinyue (April 1959): 1-4. 


\section{The politics of commemoration}

Anthropologists very often interpret ritual, a form of social acts, in relation to the needs and maintenance of a society. As suggested by Andrew Walsh, what, how, and why we remember embodies and influences the complex dialectical relationships between past and present. Commemorations, like other types of rituals, thus are themselves open to interpretation and reinterpretation. $^{24}$

The victory of the CCP in 1949 marked a new chapter in Sino-Western relation. After nearly a century of internal weakness, humiliation, and encroachment by foreign powers, China hoped to become a power in the Far East as well as the rest of the world. ${ }^{25}$ The overriding and all-embracing goal of the Chinese Communist leadership was to achieve the modernization of China so as to establish national power and prestige, reaching world power status as quickly as possible. ${ }^{26}$ Needless to say, Western music, long established in China as an icon of modernity, was a cultural facet that the PRC, with its claim to be building a modern society, could not forsake, at least, not during the first decade of the country.

In many of the commemorative writings, the fact that Chinese people had been exposed to Western music and that the young generation of Chinese performers were able to perform Western music was being emphasized. No longer was China the old nation clinging to the culture of the past, and no longer were Chinese people denied Western art. The commemorative article for the 1956 Mozart commemoration exemplified this attitude:

Chinese people can comprehend, love, and value Mozart's great arts as can the rest of the world. Chinese composers, like their counterparts in the West, have been influenced by Mozart's music, whose compositional features have enriched their own works. After the founding of the PRC in 1949, Mozart's works were more widely introduced to the [Chinese] people than before, and our younger generation performed Mozart's operas with the deepest gratitude. ${ }^{27}$

The commemoration of Western composers without doubt served a new national agenda -the opportunity for the newly established nation to reach out, and, perhaps, even to 'correct' the West's arrogant attitude toward and misunderstanding of China's own musical culture. ${ }^{28}$ That is, when

24 “When Origins Matter: The Politics of Commemoration in Northern Madagascar," Ethnohistory 48/1-2(2001): 238.

25 R. G. Boyd, Communist China's Foreign Policy (New York: Praeger, 1962), 6.

26 As pointed out by several writers, modernization, though it might not be as what such was conceived in the West, was one of the goals of the regime in its early development. See for example Benjamin Schwartz, "Modernisation and the Maoist Vision - Some Reflections on Chinese Communist Goals," in Roderick MacFarquhar edited, China Under Mao: Politics Takes Command: A Selection of Articles from "The China Quarterly" (Cambridge, Massachusetts: The M. I. T. Press, 1966), 4.

27 MA Sicong, "Jinian Mozhate dansheng erbai zhounian" [Commemoration to mark the 200th birthday of Mozart], Renmin Yinyue (July 1956): 6-7.

28 Musical diplomacy was one of the PRC's foreign-policy ploys. Musical groups of befriended nations such as Bulgaria, East Germany, and the USSR were invited to visit the PRC. In exchange, China sent performing groups to take part in those nations' festivals. In July 1951, for example, the Chinese Youth Art Troupe visited East Germany in order to participate in the Third World Youth Festival for Friendship and Peace. Participants in such exchanges were introduced especially to the musics of the nations of which the PRC approved politically and culturally. Throughout the history of the PRC, music and diplomacy have close ties. For a better understanding of the issue, see Richard Kraus's Piano and Politics in China: Middle-Class Ambitions and the Struggle over Western Music (Oxford: Oxford University Press, 1989) and Chapter 8 "Music and Power" of Melvin and Cai's Rhapsody in Red. There are two excellent studies that particularly address the issue of tours and cultural exchanges: Helen Rees's "'Naxi Ancient Music Rocks London': Validation, 
translated into diplomatic terms, they carried the mission to "break the shackles forced on China by imperialists and colonists. . . and to stand tall on the world stage." 29

It was clear that commemorations were diplomatic gestures that expressed China's willingness to work toward understanding among peoples around the world-a fact acknowledged in a great many commemorative publications and programs. What better and easier way to reach out to other nations than by celebrating those nations' musical accomplishments? No wonder the East German Consul who attended the Handel commemoration proclaimed, "The German and the Chinese people's celebration of Handel together testifies to their friendship and their willingness to work for a progressive society and world peace." ${ }^{30}$ In return, the Chinese speaker Zhao Feng praised East Germany for drawing attention to Handel's operas. "The repertoire of Handel's opera is a rich treasure. For a long time, however, these operas were overshadowed by Handel's other works. Only in workers' states such as [East] Germany are Handel's operas performed regularly-a cultural Renaissance." 31

Commemoration also functioned as an effective and comparatively inexpensive way of validating China's membership in a world community. Furthermore, honoring Western cultural figures also acknowledged certain of the West's cultural values. The 1954 Dvořák commemoration acknowledged China's entering the world stage. A member of the World Peace Council, itself organized in 1949, the PRC acknowledged support for this organization by paying tribute to cultural figures the Council chose to honor. In fact, statements to the effect that commemorated figures were "chosen by the World Peace Council to celebrate” opened practically every commemoration ceremony.

\section{Commemoration and ideology building}

Back in the 50s and 60s in the PRC, musical commemorations were often validation of domestic cultural policies. As Barry Schwartz pointed out, to 'commemorate' is to do much more than merely retrieve information: "to remember is to place a part of the past in the service of conceptions and needs of the present." 32 For instance, party-sanctioned commemorations of Dvořák, Handel or Chopin were signals to the public that their music was respectable and acceptable in the Chinese socialist regime.

In a way, commemorations were ways of establishing acceptable musical models for Chinese composers to follow. Most of all, these commemorations-and especially the commemorative articles published in conjunction with them-were measures to influence people's world views. As PRC's leaders considered it important to mobilize the arts, including music, to promote socialist ideology,

Presentation, and Observation in the First International Naxi Music Tour," Ethnomusicology 46 (3/2002):432-455, and Nancy Guy's "Brokering Glory for the Chinese Nation: Peking Opera's 1930 American Tour," in Comparative Drama 35 (3,4/2001/02): 377-392.

29 XIE Yixian, Zhongguo dangdai waijiaoshi: 1949-2001 [A history of Chinese foreign diplomacy] (Beijing: Zhongguo Qingnian Chubanshe, 2002).

30 "Shoudao wenyijie yinyuejie jihui: jinian Hengdeer shishi erbai zhounian" [Capital's literary and musical circles gathered to commemorate the bi-centennial of Handel's death], Renmin Yinyue (April 1959): 4.

31 Zhao, "In commemoration of the great German composer George Federic Handel's 200th death," 2.

32 Barry Schwartz, "The Social Context of Commemoration: A Study in Collective Memory," Social Forces 61/2 (1982): 374. 
one important function of commemoration was to propagate socialist values by means of appropriate 'socialist' musical models: depictions of composers or performers from a socialist perspective. ${ }^{33}$

Consider the 1956 Mozart commemorative article (part of which is quoted above), which portrays the composer as a rebel, who, although born in an "era of capitalist revolution-the French Revolution-revolted against the patronage and other forms of economic and political repression." ${ }^{34}$ Mozart's leaving Salzburg for Vienna in 1781 was described as a result of the composer's refusal to be "treated as a servant" and his fight for "artistic freedom" and "ridding himself of control by the church and nobility." ${ }^{35}$ Mozart's works were portrayed as "representative examples of capitalist revolution, nevertheless embedded with progressive elements." 36 The composer's interest in Freemasonry was cited as an example of his aspiring to the struggle for freedom, equality, and brotherhood and he also won praise for having devoted his short life to anti-feudalistic callings. ${ }^{37}$

Handel, too, was portrayed as a proto-socialist in the bicentennial celebration of his death in 1959. In the official commemorative article, the composer was evaluated in a revolutionary context and praised as a hero who had lived up to socialist ideals:

Humanism, an $18^{\text {th }}$-century democratic ideal, was the ideological foundation for many [contemporary] philosophers and artists. Their strong belief in the strength and talent of their fellow human beings led them to understand the obstructive influence of feudalism on human development and its inevitable collapse [as a social system]. . . The works [of such artists] reflected their longing for truth and justice [and for a society in which] scientific truth would replace the ignorance of religion and socialist justice would deter the cruelty of autocratic feudalism. Handel was a progressive artist who embodied the aspirations of this era. ${ }^{38}$

Despite its Biblical origins, Handel's oratorio Israel in Egypt was hailed as embodying the composer's humanism because it dealt with "the common people's fate and suffering, happiness and hope, the joy of liberation." Furthermore, Handel's choice of subject matter was epitomized as a "language" in which he could "express his hopes on behalf of democracy, national independence, and the pursuit of justice and peace."

Close relationships between ideology, political propaganda, and the arts were evident in the commemorative publications. Consider the Chopin celebrations in 1960. Like Dvořák and Handel, Chopin was chosen as one of the World's Renowned Cultural Figures by the World Peace Council to mark the composer's $150^{\text {th }}$ birthday in 1960, and his anniversary was celebrated in approximately the same way as those of Mozart and Handel. An official concert took place in Beijing on 22 February of that year, as well as in other cities. A number of Chopin studies (translated from the Russian or written by Chinese scholars) were published. An article about him published in Renmin Yinyue in

33 For further discussions on socialist realism and its impact on the musical scene of the PRC, see the present author's "Socialist Realism and Music in the People's Republic of China," Socialist Realism and Music - Colloquia Musicologica Brunensia, 36 (2001) (Praha: KLP., 2004),135-144; and "The Making of a National Musical Icon: Xian Xinghai and His Yellow River Cantata," in Music, Power, and Politics, ed. by Annie J. Randall (New York: Routledge, 2005), 87-112.

$34 \mathrm{Ma}$, "Commemoration to mark the 200th birthday of Mozart," 6.

35 Ibid.

36 Ibid.

37 Ibid.

38 Zhao, "In commemoration of the great composer George Federic Handel's 200th death," 2. 
1960 opened in a manner by then not unfamiliar to Chinese readers -it articulated the PRC's position toward the West:

Nowadays, the efforts of peoples around the world have forced the imperialists to conceal their imperialistic policy. They put on the new outfit of "peace" in order to disguise their military expansion. This is the calculated "double-sidedness" of imperialism. American imperialism is the use of "American lifestyle" and "yellow culture (pornographic culture)" to pollute the spiritual life of the world's peoples in order to paralyze their fighting. The motive of internationalism is to kill national awareness and the will of people all over the world. ${ }^{39}$

Hardcore pronouncements such as this one epitomized contemporary political and cultural attitudes. So did a speech entitled "Music in the Service of Workers, Peasants and Soldiers" delivered in the same year by Lü Ji, then China's leading musical spokesman at the 2nd Representatives' Conference of the Chinese Musicians Association. Lü drew a firm line between "proletarian” and "capitalist" music. "No matter whether it is called new music or jazz, it is permeated with capitalist poison, [and] is a tool of Imperialism. Twelve-tone music, serial music, [or] electronic music, etc. is not real music, but a reflection of pathetic craziness and mental breakdown ... typical of Imperialism and Colonialism." 40

Official disapproval of the West, which was seen as belonging to another camp-that of Imperialism-is omnipresent in the commemorative article about Chopin. Western music critics, for example, were criticized as a "class" for their fixations on Chopin's lyricism. "To insist on the lyrical," Zhao Feng wrote, "was to render Chopin's music sentimental and salon-oriented; qualities that could not be tolerated under socialist realism." ${ }^{41}$ In the article, Chopin's music was described as sorrowful (as well as optimistic), embodying the fact that Chopin himself had imaginatively anticipated the agonies of revolution in Poland as well as the eventual socialist triumph of the Polish people. Interestingly enough, Chinese commentators argued that Chopin and his music could only be understood by the citizens of a liberated, "democratic Poland"; pronouncements of this kind, of course, denied any right to Chopin's music on the part of listeners throughout the non-Communist world. Above all, the commentator placed the PRC in close proximity to Poland, based on the assumption that the peoples of both nations had both suffered under Western oppression and could sympathize with Chopin's nationalist and anti-feudalist compositions. The commentator also gave credit to the CCP for making it possible for Chinese audiences to appreciate Chopin. Without Communism, he maintained, it would have been impossible for the two nations to develop precisely this kind of aesthetic, political, and cultural relationships. He also pointed out that Chopin's music was "sweeping” China! ${ }^{42}$

39 ZHAO Feng, "Shao Pang - Polan renmin weida de geshou” [Chopin - A great singer of the Polish people], Renmin Yinyue (Feb 1960): 5.

40 LÜ Ji, "Wei gongnongbing fuwu de yinyueyishu: zai zhongguo yinyuejia xiehui dierci huiyuan daibiaodahui shang de baogao" [Music in the service of workers, peasants and soldiers: a report on the 2nd representatives' convention of the Chinese Musicians Association], Renmin Yinyue (July and August 1960): 20.

41 Zhao, "Chopin - A great singer of the Polish people," 7-8.

42 Ibid. 


\section{Commemoration, domestic policy, and diplomatic relations}

Musical commemorations in the PRC during the early years were thermometers that recorded the rising and falling temperatures of China's relations with Western nations. Composers chosen for celebration were largely composers from the so-called communist bloc nations. As a communist regime, the PRC's leaders accepted the Marxist-Leninist belief that the world was divided into two hostile and irreconcilable spheres: socialist and capitalist-imperialist. ${ }^{43}$ Equally, the U.S. and Western European countries were suspicious of communism and hostile toward the PRC and the communist countries. After the founding of the PRC in October 1949, it was natural that China's leaders turned to the USSR and the so-called "second world" or communist bloc countries: Albania, Bulgaria, Czechoslovakia, East Germany, Hungary, Poland, Rumania, and Yugoslavia. ${ }^{44}$ In 1950, China and the USSR signed the Treaty of Alliance, Friendship, and Mutual Assistance, which promised the PRC Soviet economic and military aid as well as other kinds of assistance. The USSR also exercised a powerful ideological influence on Chinese cultural policy. The CCP's reliance on Soviet artistic principles was most apparent during the PRC's early years and its influence the most extensive and far-reaching. ${ }^{45}$ It is scarcely surprising, therefore, that China joined the USSR in celebrating anniversaries of Chaliapin's, Glinka's, Rimsky-Korsakov's, and Tchaikovsky's births or deaths, occasions of importance perhaps to the USSR, but secondary to the rest of the world. The much lower-profile commemoration of Tchaikovsky's 120th birthday in May 1960 may have been a telltale sign of strained Sino-Soviet "friendship" that led the withdrawal of Soviet technicians from China in the following August, which was followed by a complete breakdown of relations and accusations that the Soviets were "revisionists" rather than "real” socialists.

It is interesting that there were no celebrations of French or Italian composers, for example, even though the centenary of Debussy's birth fell in 1962, the bicentennial of Rameau's death in 1964, and the sesquicentennial of Verdi's birth in 1963. Perhaps worth noting is that relations during the years in question between China (on the one hand) and France and Italy (on the other) were anything but warm. Sino-French relations got off to a bad start during the early years of the PRC's history. In 1950, the establishment of the Ho Chi Minh government in Vietnam drove a wedge between China and the French Republic. The French government's alliance with the United States also drove the two nations further apart. As Jean-Luc Domenach pointed out, the Chinese press was so hostile to anything French that "[it] scarcely missed an occasion to vent its contempt for French militarism and colonialism." ${ }^{46}$

Despite the political tension, there were still a limited amount of cultural exchanges between the two nations. In 1955, French writers Simone de Beauvoir and Jean-Paul Sartre visited Beijing, and it was also in the same year that a Peking Opera troupe performed at the International Theatre Festival

43 Hsueh, China's Foreign Relations, 17.

44 Ibid., 21. The ex-USSR was the first to have diplomacy with the PRC, on 3 October 1949, two days after the founding of the country. After the Soviet lead, other socialist countries followed. See XIE Yixian. ed. Zhongguo dangdai waijiaoshi: 1949-2001 [A history of Chinese foreign diplomacy] (Beijing: Zhongguo Qingnian Chubanshe, 2002), 6.

45 For more information, see YE Chunzhi, "Sulian xuepai dui zhongguo yinyue meixue de yingxiang 1949-1990" [The Soviet school's influences on Chinese music aesthetics], in Papers and Proceedings of the International Seminar on Aesthetic of Chinese Music (Hong Kong: Center of Asian Studies, The University of Hong Kong, 1995).

46 Jean-Luc Domenach, “Sino-French Relations: A French View” in Hsueh's China’s Foreign Relations. 88. 
in Paris in June. In 1956, an article on French music appeared in Renmin Yinyue. Entitled "French music and French composers," it had been translated from French into Chinese. ${ }^{47}$

Significantly, 1956 was the year of the "Hundred Flowers" or the so-called "Directive of the Two Hundred" - the "Let a hundred flowers bloom and a hundred schools of thought contend" campaign: a period of purported open-mindedness that was supposed to encourage diverging views but unfortunately became an excuse to clean house: to identify and punish the dissidents. ${ }^{48} 1956$ was also the year of Mozart's 200 birthday commemoration. We should not forget, however, that Mozart was an Austrian composer and Austria was part of the alliance of the West. Perhaps not coincidental, three years later, the sesquicentennial of Haydn's death was utterly ignored in China. In the same year, there was also an article about the Boston Symphony Orchestra, translated from Russian into Chinese, by Li Delun, a sign of the nation's interest in the superpower of the West. ${ }^{49}$ This was the first non-hostile article on American-related musical matters. Aside from issues of communist ideology, the PRC's hostility toward the United States was a result of American support for the Nationalist government (which still governed Taiwan after 1949 and antedated the establishment of the Mainland's communist government). Continued American insistence on the legitimacy of the Taiwanbased Nationalist government was interpreted by the CCP as interference in China's domestic affairs. Incidents such as the trade embargo and the Korean War further strained relations between China and the United States.

All this perhaps accounted for the CCP's strong official disapproval of American music throughout the 1950s, 1960s, and early 1970s. In the June 1951 issue of Renmin Yinyue, for example, the first year the journal appeared in print, Liao Fushu published an article entitled "Criticism of American Music." ${ }^{50}$ Liao vilified "the gimmicks and sexual appeals" of American music overall, an art he considered "characteristic of a nation on the verge of collapse." 51 American popular music and Broadway shows were especially condemned, because, as Liao put it, "proper love songs, in the hands of Americans," became nothing more than "derogatory lyrics, and healthy dances turned into cancans of promiscuity." ${ }^{2}$ Jazz, which had flourished in Shanghai in the 1930s and 1940s, was criticized especially severely. ${ }^{53}$ In an article titled "Comments on American Jazz" by Wu Yongyi, America's then-widespread form of popular entertainment was described as a type of "noisy, vulgar, and unrefined music used for dancing," and "a product of the capitalist class," nothing more or less than "a stimulus for decadent life styles."

47 The article appeared in Renmin Yinyue (July 1956): 27-28. An article entitled "French Friends of China, Old and New" by the French writer Jean Chesneaux, director of studies at the Ecole Practique des Hautes Etudes at the Sorbonne, and editor-in-chief of the French bi-monthly journal Paris-Pekin appeared in China Reconstructs 7 (7/1958): 20-22.

48 Regarding the movement itself, see Rene Goldman, "The Rectification Campaign at Peking University: May-June 1957," in Roderick MacFarquhar, ed. China under Mao: Politics Takes Command (Massachusetts: the M.I.T. Press, 1966), 255-270. A good introduction on its impact on the musical scene can be found in JU Qihong's Xin Zhongguo yinyueshi [A History of Chinese Music: 1949-2000] (Changsha: Hunan Meishu Chubanshe, 2000.)

49 LI Delun later became the PRC's most prominent conductor after the Cultural Revolution. Regarding Li's career, see LUO Yunyun, Li Delun Zhuan [The Life of Li Delun] (Beijing: Zhuojia chubanshe, 2001).

50 LIAO Fushu, "Chi meiguo yinyue" [Criticism on American Music], Renmin yinyue, (June 1951): 8-10.

51 Ibid., 8.

52 Ibid.

53 For jazz in China in the 20s and 30s, see Andrew Jones, Yellow Music: Media Culture and Colonial Modernity in the Chinese Fazz Age (Durham, NC: Duke University Press, 2001).

54 WU Yongyi, "Ping meiguo jueshi yinyue" [Comments on American Jazz], Renmin Yinyue (Freburary 1951): 6-7. 
The CCP's paranoia toward the US was translated into a twisted understanding of American music as "capitalist art," an invader that attacked its listeners and poisoned their souls. For Chinese critics, the songs of Kern, Berlin, and Gershwin provided only temporary and corrupt relief, "like prostitution," and catered to people's "vulgar taste." ${ }^{55}$ In a later article on jazz, Chinese critics Tong Changrong and Wang Ying adopted a similar view. ${ }^{56}$ Musical characteristics associated with jazz were examined exclusively through ideological lenses. Jazz progressions, for instance, were mocked as "make-up" that disguised the simple beauty of traditional functional harmony; seventh chords and non-harmonic tones were derided because they were perceived as covering up the unhealthy vocal vibratos employed by many popular singers. ${ }^{57}$ Nor did Chinese critics miss any opportunities to substantiate anti-jazz and anti-American arguments by publishing translations of Western writers' works that expressed similar political-cultural convictions. An article entitled "Sweden's Disapproval of American Jazz” was published in 1955 in Renmin Yinyue. ${ }^{58}$

One American performer was however singled out for flattering attention. ${ }^{59}$ This was Paul Robeson (1898-1976), an African-American actor and singer who launched his professional career in 1924. In 1958, CCP officials honored Paul Robeson's $60^{\text {th }}$ birthday with high-profile commemorative ceremonies similar to those lavished on Dvořák, Handel, and Mozart. Guo Meiruo, president of the Chinese World Peace Council and the Union of Chinese Literature and Art, gave a speech in Robeson's honor.

Celebrated for his "resonant voice and the ability to project a humane spirit" in his many and various roles, Robeson visited the USSR in 1934 and was impressed by socialism as a political and cultural system. Embracing communism, however, all but ruined his career: for eight years his American passport privileges were suspended and he was also banned from making public appearances anywhere in the United States. Instead, during the 1950s, Robeson was forced to move to Europe, where he was able to pursue his performing career; he returned to his native land only in $1963 .{ }^{60}$

Several articles were devoted to Robeson in the April 1958 issue of Renmin Yinyue. ${ }^{61}$ In one of these articles, the singer was hailed as a defender of world peace and a fighter for racial equality. ${ }^{62}$ Statements attributed to Robeson were also quoted or paraphrased in these publications, including autobiographical accounts of his slave origins, the suffering he endured on account of racial

55 Ibid., 6.

56 TONG Changrong and WANG Ying, "Meiguo jueshi yinyue“ [American Jazz], Renmin Yinyue (April 1958 ): 36.

57 Ibid.

58 Renmin Yinyue (November and December 1955): 56. Had CCP officials been cognizant of Theodore Adorno's devastating dismissal of American popular music, they undoubtedly would have reprinted his article too. According to Theodor W. Adorno, pop music in capitalist countries was a "catharsis for the masses, but catharsis which keeps them more firmly in line," inspiring at best a merely "mechanical collectivity." "On Popular Music," [1941; with George Simpson], Essays on Music, ed. Richard Leppert; trans. Susan H. Gillespie (Berkeley, California: University of California Press, 2002), 461-462.

59 See LIU Hong, " 'Masha'heiren gequ he Fusite” [Masha the black singer and Stephen Foster], Renmin Yinyue (April 1963):27-30.

60 Columbia Encyclopedia, Sixth Edition, 2005.

61 See GONG Qi, “Xiang Baoluo Luoboxun xuexi” [To learn from Paul Robeson], Renmin Yinyue (May 1958):29; LÜ Ji, "Baoluo Luoboxun de gesheng shi chongbupo dabuduan de" [The song of Paul Robeson cannot be stopped], Renmin Yinyue (April 1958): 2; ZHAO Feng, "Heping Zhanshi, yishu dashi, weida de meiguo gongmin, zhongguo renmin de pengyou" [Defender of peace, master of art, great American citizen, and a friend of Chinese: a report delivered at the 60th birthday celebration of black singer Paul Robeson], Renmin Yinyue (April 1958): 2-4.

62 Lü, "The song of Paul Robeson cannot be stopped," 2. 
discrimination, and so on. ${ }^{63}$ Robeson's politicized and social-critical views were emphasized, and he was praised especially for such pronouncements as "I serve the people; I shall always serve them through art that is politically motivated. An artist cannot be without political belief. . . Music to me is a social weapon, and no artist can work outside politics. As for me, I am always with the people and on their side. ${ }^{64}$

Robeson, in other words, was publicly accorded iconic status in the PRC as a socialist hero "who used music to serve people and fight capitalist imperialism." ${ }^{65}$ His popularity, origins, political struggles and temporary banishment from the United States made him an archetypical victim of American imperialism. No wonder he was hailed as a "genuine American citizen" as well as "a friend of those who want to fight against oppression and colonization, as well as world peace." ${ }^{\prime 6}$ In an article entitled "Learning from Paul Robeson," Gong Qi went so far as to challenge Chinese musicians to emulate Robeson by enlarging their repertoires and letting "the masses" (in this case, audience members) call for their own, favorite songs at concerts. ${ }^{67}$

\section{Conclusion}

The PRC's relations with Western nations became increasingly strained after 1964 as China was moving toward radical policies. In the face of the three directives introduced to the musical arena in 1964 - compositions be revolutionary, nationalistic, and masses-oriented - as required. Western composers, likewise, were no longer acknowledged as socialist or proto-socialist heroes. The last commemorative ceremony of any importance was held in 1961, in honor of the sesquicentennial of Liszt's birth. Two years later, the sesquicentennial of Verdi's birth was celebrated especially in Italy, but it was ignored in the PRC. During the ten-year period (1966-1976) of the Cultural Revolution, not only Western music but all other cultural forms went through the darkest phase in the history of the country. ${ }^{68}$

The Open Door policy introduced by Deng Shaoping in 1978 put the country onto a new path. In recent years, commemoration of Western composers was no longer on the national agenda. The nature of the commemoration was also quite different from those of the past. On the one hand, Chinese composers were much more often celebrated than Western composers. On the other, elaborate "official” celebrations like those accorded Dvořák, Handel, Mozart, and Liszt during the 1950s and 1960s were non-existent. In 1991, for example, the bicentenary of Mozart's death was recognized in China: a concert of the composer's works presented in Beijing by the Central Philharmonic and several academic conferences were devoted to Mozart's career and legacy. Yet

63 Zhao, "Defender of peace," 2.

64 Ibid., 3.

65 Ibid.

66 Ibid., 4.

67 Gong, “To learn from Paul Robeson,” 29.

68 For Chinese musicians' experiences during the cultural revolution, see for example Y. R. Mao, "Music under Mao, its Background and Aftermath," Asian Music 22/2(1991): 97-125; A. Schimmelpenninck and F. Kouwenhoven, "The Shanghai Conservatory of Music: History \& Foreign Students' Experiences," CHIME (6/1993): 56-91; Kraus, Piano and Politics in China; Chapter 7 of Melvin and Cai's Rhapsody in Red. 
politics played little part in these activities. Even the commemorative article written in Mozart's honor almost entirely ignored social and political issues (except for the concluding paragraph). ${ }^{69}$

In the past three decades, the PRC has changed drastically, at least economically if not altogether politically, witnessing enormous and important transformations. The Open Door policies and economic reforms resulted in a relaxation of ideological controls, especially in the cultural arena. ${ }^{70}$ The Cultural Revolution had done enough damage to China, and the CCP had learned its lesson: classical music, especially Western music, simply wasn't as important as other issues. Besides, since the late 1970s, China has repaired her relations with Western countries and cultural diplomacy was gradually decreasing in importance. With the ascension of Chinese musicians onto the world stage of Western music in the recent years, composers Tan Dun and Chen Yi, pianists Lang Lang and Li Yundi, to name but a few of the most representative, and the flourishing classical music scene in the PRC with millions of youngsters learning the piano and other Western musical instruments, the celebration of Western musical figures has become more an artistic and musical event than a political one.

Nonetheless, the commemoration of Western composers in the PRC during the early years of the country's history remains an important and intriguing phenomenon. There is no doubt that officially sanctioned celebrations and publications provided effective ways of evaluating the role of art in an emerging socialist society. Musical commemorations were rituals as well as acts of political maneuver for diplomatic, ideological as well as propaganda purposes. Equally, one argues, they were and still are manifestations of cultural contacts and exchanges. In fact, the commemorative activities in the PRC had helped a great many Chinese men and women gain some sense of Western culture and its musical accomplishments- at a time when access to Western music of many kinds was severely limited. Thus, in many respects, the commemorations of Western musical figures in the PRC concord with Bohlman's assessment, "[the] belief in the power of music to represent in complex ways is virtually universal." 71

69 In WEI Min's article, Mozart is described as a “pre-revolutionary composer who succeeded the humanism of the Renaissance and was affected by the Enlightenment of the eighteenth century. . . Although [Mozart] did not actively participate in meaningful social revolution, his creative works were full of feelings [and] written for those who fought for their own happiness, even though the conflicts and dramas [in Mozart's compositions] were not as well developed as those in Beethoven's." "Mozhate youmei de yinyue yongliu renjian: jinian Mozhate shishi erbai zhounian” [Mozart's music will remain with us forever: commemoration of the 200th anniversary of Mozart's death], Renmin Yinyue (December 1991 ): 37.

70 Richard C. Kraus's recent book The Party and the Arty in China: The New Politics of Culture (Lanham, Maryland: Rowman \& Littlefield Publishers, 2004) is a study on China's cultural reform after the late 1970s as a result of the economic reform in the country.

71 Bohlman, "Music as Representation," 206. 